\title{
高流動コンクリートのフレッシュ性状の経時変化および チキソトロピーに関する理論的考察 \\ THEORETICAL ANALYSIS ON TIME-DEPENDENCE OF FLUIDITY AND THIXOTROPY OF HIGH FLUIDITY CONCRETE
}

\author{
李 柱 国*, 谷川恭雄**, 森 博 嗣*** \\ Zhuguo LI, Yasuo TANIGAWA and Hiroshi MORI
}

\begin{abstract}
This paper deals with the time-dependence of fluidity and thixotropy of high fluidity concrete mixed by adding polycarboxylate-based superplasticizer. With taking both the hydration and the physical flocculation of cement particles into consideration, the increase of apparent viscosity and Bingham's constants with the elasped time of standstill, and the time-dependence of apparent viscosity in agitated state were investigated theoretically. It was concluded that whether the increase of apparent viscosity or Bingham's constants in stationary state or the time-dependent behavior of apparent viscosity in agitated state, are dependent on the hydration rate of cement and are also affected by the dosage of superplasticizer, temperature, the reference time of investigation and the dispersion degree of cement particles at the reference time. Moreover, the influences of the magnitudes of applied stresses and their lasting times on the shape of hysteresis loop of shear strain rate-shear stress relationship and its surrounding area were inquired quantitatively.
\end{abstract}

Keywords: High fluidity concrete, Time-dependence of apparent viscosity, Thixotropy, Hysteresis loop, Physical flocculation, Hydration rate 高流動コンクリート，見かけ粘度の経時変化，チキソトロピー，ヒステレシス・ループ，物理凝集，水和反応速度

\section{1. はじめに}

高流動コンクリートは、フレッシュ時の充填性を高め、打設時の 締固め作業を不要とするコンクリートである。その自己充填特性を 実現する最適な調合を決定するためには、高流動コンクリートのレ オロジー性状に対する詳細な検討および精確な評価が不可欠である。

これまで、高流動コンクリートのレオロジーに関する研究は、その コンシステンシーの評価試験法および影響要因に集中していたが 1 ,2)、 高流動コンクリートのフレッシュ性状の時間（静置時間または摚汼時 間）依存性およびチキソトロピー特性が存在することは報告されてい る 3,4,5)。フレッシュコンクリートのレオロジ一試験法はまだ確立され ておらず、試験過程で分離により材料性質が不安定性となるため、ス ランプフロ一值の経時変化などに関する研究は報告されているもの の6)、その他のフレッシュ性状の経時変化およびチキソトロピ一特性 に関する実験は困難であるため、定量的な解明には至っていない。 本研究では、高流動コンクリートのフレッシュ性状の経時変化およ びチキソトロピー特性の解明を目指して、理論解析を行い、ポリカル
ボン酸系高性能 $\mathrm{AE}$ 減水剂を添加した高流動コンクリートの見かけ粘 度に及ぼす静置時間の影響、せん断時の見かけ粘度の経時変化特性お よびヒステレシス・ループの影響要因について定量的に考察する。

\section{2. せん断流動速度およひ見かけの祜度}

サスペンションである高流動コンクリートを、変位が時間に依存 する性質を持つセメント粒子群と、持たない骨材粒子群からなり、 内部摩擦を持つ粒子集合体とみなした時、平均粒子接点角が零と近 似できる場合には、既往の研究によって、流動曲線は図 1 に示すよ うであり、せん断流動速度 $(\gamma)$ およびせん断応力 $(\tau)$ とせん断速度の 比である見かけの粘度 $\left(\eta_{a}\right)$ は、それぞれ式(2-1)および式(2-2)で表さ れるク。

$$
\begin{aligned}
& \dot{\gamma}=C_{1} \exp \left(-\frac{E}{k T}\right) \sinh \left[C_{2}\left(\tau-\tau_{y}\right)\right] \\
& \eta_{a}=\frac{\tau}{C_{1}} \exp \left(\frac{E}{k T}\right) \frac{1}{\sinh \left[C_{2}\left(\tau-\tau_{y}\right)\right]}
\end{aligned}
$$

Domestic Research Fellow, Department of Building Materials and Components, Building Research Institute, Dr. Eng.

Prof., Division of Environmental Engineering and Architecture, Graduate School of Environmental Studies, Nagoya University, Dr. Eng.

Assoc. Prof., Division of Environmental Engineering and Architecture, Graduate School of Environmental Studies, Nagoya University, Dr. Eng. 
ここに、 $C_{1}=\frac{2 k T}{h} N_{c} E_{c m}, C_{2}=\frac{S_{d} E_{c m}}{2 k T N_{c}}$

$E: 1$ 個のセメント粒子が移動する時、摩擦抵抗以外の、分散を 妨害するポテンシャルエネルギ障壁の平均值、 $N_{c}$ ：単位面積に おけるセメント粒子の個数、 $\Lambda_{m m}$ : セメント粒子の移動開始から 新たな安定位置までの平均移動距離、 $k$ : ボルツマン定数、 $T$ : 絶対温度、 $h$ : プランク定数、 $S_{d}$ : セメント粒子群およびその周 りにおける水膜の総体積によって決定される応力分配保数

式(2-1)中の $\tau_{y}$ は真の降伏応力、つまり、内部摩擦として支持され るせん断応力であり、式(2-3)で与えられる。

$$
\tau_{y}=\sigma_{n} \tan \phi_{m}+C_{w}
$$

ここに、 $\sigma_{n}$ : せん断面上の垂直応力、 $\phi_{m}$ : 粒子の平均内部摩擦角、

$C_{w}:$ 水の表面張力に関連する定数

ポリカルボン酸系などの高性能 $\mathrm{AE}$ 減水剤を添加する場合には、セ メント粒子の反発力は、主にその表面に吸着されている高分子の立体 障害効果によるものであると考えられ、この立体障害勃果は、高分子 吸着層の密度、つまり吸着量に依存する混合効果之吸着首厚 $(\delta)$ に比例 する弾性効果からなっている。前者は隣接する高分子層が互いに侵入 する時の抵抗であり、後者は粒子表面の接近に対して、高分子鎖の弾 性力による障害力である ${ }^{8}$ 。 $\delta$ は高分子の構造特性に依存する ${ }^{9}$ ため、 $\mathrm{AE}$ 減水剂が一定の場合には定数となる。弾性効果によって、高分子を 吸着したセメント粒子は、吸着層表面以遠のある位置まで接近でき、 全ポテンシャルエネルギ曲線㤬、図 2 中の曲線(i)と(ii)のようになる。 粒子の安定接近位置は、 $\delta \sim 2 \delta$ の間にあり、全ポテンシャルエネルギ 曲線の届折点(ここでは、第二極小点と称する)にある。高分子層の侵入 程度は吸着層の密度に依存するため、密度が小さくなると、侵入程度 が大きく、図 2 中の曲線(b)と(ii)に示すように、立体障害の混合項の工 ネルギ曲線は左下へ倒れて、全ポテンシャルエネルギ曲線およびその 上にある第二極小点の位置は左下ヘシフトする。一方、高分子を吸着 しないセメント粒子は、自由高分子の枯渴効果と van der Waals 力によ って粒子表面まで疑集し、その全ポテンシャルエネルギ曲線は図 2 中 の曲線(iii)のようになる。本研究では、吸着層厚の 2 倍以上距離が離札 ている粒子を分散粒子、その以外の粒子を凝集粒子と呼ぶことにする。

図 2 に示す全ポテンシャルエネルギ曲線によって、凝集セメント 粒子と分散セメント粒子のポテンシャルエネルギはともに引カエネ ルギであり、それぞれの平均值を $E_{f}, E_{d}$ と記すると、式(2-1)中の $E$ は式(2-4)で表される。

$$
E=\frac{N_{c f} E_{f}+N_{c d} E_{d}}{N_{c}}=E_{f}-\left(E_{f}-E_{d}\right) \cdot \frac{N_{c d}}{N_{c}}
$$

ここに、 $N_{c f,} N_{c d}:$ それぞれ単位面積において 凝集しているセメント粒子と分散して いるセメント粒子の個数

\section{3. 觧監に伴うレオロジー定数の増加}

\section{1 見かけ粘度の経時変化}

フレッシュコンクリートを練り混ぜた直後、 または摚汼やレオロジー実験の途中に静置させ ると、経過時間とともに流動性が低下する。セ

メントの水和過程から判断すると、練混ぜ後 12 時間における流動 性の変化は、セメント粒子の凝集が支配的な影響を及ぼしていると 考えられる。セメント粒子凝集のメカニズムとしては、粒子の Brown 運動による衝突という物理的な原因と、水和反応に起因する化学的 な原因が挙げられる 10, 11)。

立体障害効果による反発力が粒子間に作用する場合において、セ メント粒子の Brown 運動による衝突凝集は、エネルギ障壁で妨害さ れることはなく、凝集による分散粒子の減少速度は式(3-1)で与えら れる9。立体障害が存在するため、笽密にい元ば、この凝集は粒子 の表面の接触ではなく、ある程度の接近という意味になる。

$$
\frac{\mathrm{d} N_{\mathrm{cd}}}{\mathrm{d} t}=-\frac{8 k T \cdot N_{c d}^{2}}{3 \eta}
$$

ここに、 $t:$ 流動性の経時変化を考察する基準点からの経過時間、 $\eta:$ 溶媒の粘度

セメント粒子の物理凝集の化学的な原因として、エトリンガイト などの水和生成物によって、粒子表面の凝集エネルギの增加に加え て、セメント粒子の表面にある高性能 $\mathrm{AE}$ 減水㓮の吸着首が水和物 で覆われ、その分散効果が低下するためと推察されている ${ }^{12), 13 \% 。 こ ~}$ れによって、エトリンガイトなどの結晶性物質が液相に生成すると、 セメント粒子を中心とする固体の表面積が増加し、この固体表面に おける高性能 $\mathrm{AE}$ 減水剤の吸着層の密度が低下する。その結果とし て、ポリカルボン酸系の高性能 $\mathrm{AE}$ 隇水剛が添加されている場合に は、図 2 に示す粒子間のポテンシャルエネルギ曲線は左下ヘシフト して、第二極小点における引カポテンシャルが增加し ${ }^{81}$ 、凝集粒子 の分散エネルギ障壁が高くなると考えられる。

エトリンガイトを生成する $\mathrm{C}_{3} \mathrm{~A}$ 成分の反応率の変化は、最も一般 的な式として、図3および式(3-2)によって表される ${ }^{14) 。}$

$$
\left[1-(1-\omega)^{1 / 3}\right]=s \cdot t^{\prime}
$$

ここに、 $\omega: \mathrm{C}_{3} \mathrm{~A}$ 成分の反応率、 $s: \mathrm{C}_{3} \mathrm{~A}$ 成分の反応速度定数、 $t^{\prime}$ : 接水からの経過時間

上式の反応速度定数 $s$ は、 $\mathrm{C}_{3} \mathrm{~A}$ 成分の物理化学特性および温度に 依存するものである。その温度依存性が Arrhenius 法則に従うと仮定 すれば、式(3-3)となる。

$$
s=s_{20} \cdot \exp \left[B \cdot\left(\frac{1}{293}-\frac{1}{T}\right)\right]
$$

ここに、 $s_{20}: 20^{\circ} \mathrm{C}$ における $\mathrm{C}_{3} \mathrm{~A}$ 成分の反応速度定数、 $B: \mathrm{C}_{3} \mathrm{~A}$ 成 分の活性化エネルギに関連する定数

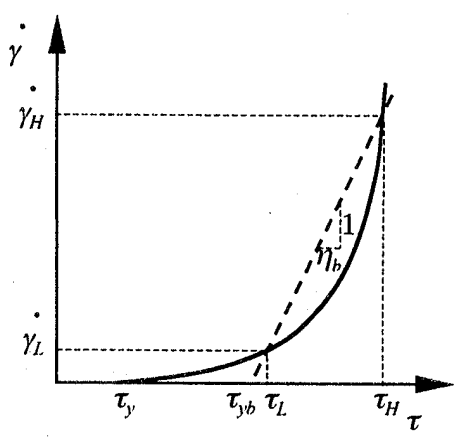

図 1 高流動コンクリートの流動 曲線と Bingham 定数

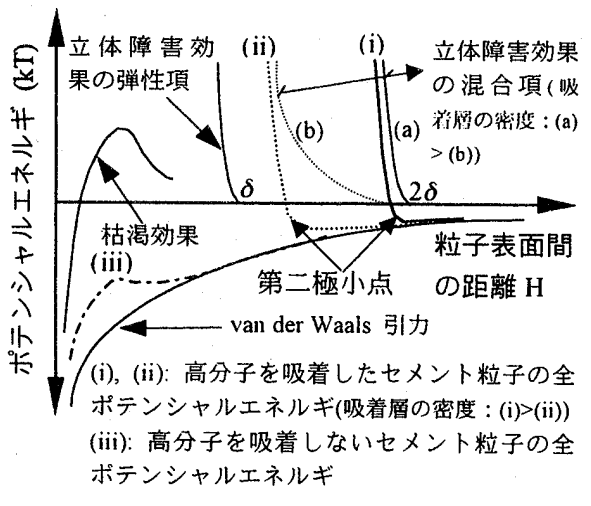

図 2 セメント粒子間のポテンシャルエネル 


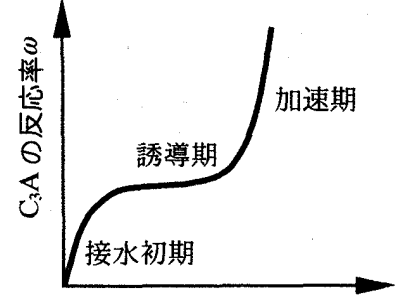

接水からの経過時間 $\boldsymbol{t}$

図 $3 \mathrm{C}_{3} \mathrm{~A}$ 反応率の経時変化

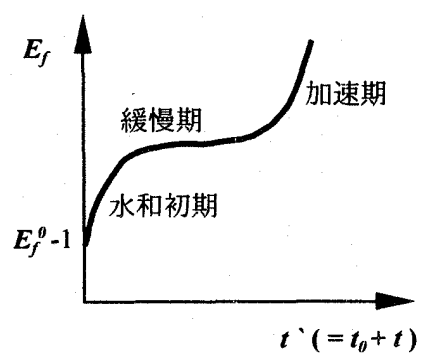

図 4 凝集セメント粒子の分散エネ ルギ障壁 $E_{f}$ の経時変化の仮定
凝集粒子の分散エネルギ障壁 $E_{f}$ の経時変化は、水和初期では主要 な水和生成物であるエトリンガイトの生成量に依存し、 $\mathrm{C}_{3} \mathrm{~A}$ 成分の 反応率の変化によって図 4 のように仮定され、式(3-4)で表される。

$$
E_{f}=E_{f}^{0}-\left[1-s\left(t_{0}+t\right)\right]^{3}
$$

ここに、 $E_{f}^{0}$ : 定数、 $\left(E_{f}^{0}-1\right)$ : 水和生成物が生じない仮想状態にお けるセメント粒子の分散エネルギ障壁、 $t_{0}$ : 接水から流動性 の経時変化を考察する基準点までの経過時間であり、コンク

リートの練混ぜ時間より小さくはならない。

高性能 AE 減水剂が過剩添加率 $\kappa$ (添加量之飽和吸着量の比, $\ltimes 1$ ) で過剩添加される場合、水和生成物が生じても、過剩分の高分子が 吸着されて吸着層の密度が変わらないため、凝集粒子の分散エネル ギ障壁 $E_{f}$ は、式(3-5)の第 1 式に示すように、ある時間 $t_{c}$ まで飽和吸 着状態の初期値 $\left(E_{j s}^{0}-1\right)$ を維持できる。この効果は、 $E_{f}$ が過剩添加分 によって徐々に減少することに相当する。もし、 $E_{f}$ の総減少量が過 剩分の量および飽和吸着状態の $E_{f}$ 值に比例すると仮定して、 $(\kappa-1)$ $\left(E_{f s-1}^{0}\right.$ )とすれば、 $t_{c}$ は式(3-4)によって式(3-5)に示すように求められ る。経過時間が $t_{c}$ を超えると、過剩分の高分子がすべて吸着される ため、吸着層の密度が時間とともに減少し、 $E_{f}$ が增加する。この時 の $E_{f}$ の経時変化は、過剩分の分散エネルギ障壁の低隇効果を考虑し た上、式(3-4)によって式(3-5)の第 2 式で表される。

$$
\begin{aligned}
& E_{f}= \begin{cases}E_{f s}^{0}-1 & \left(0 \leq t_{0}+t \leq t_{c}\right) \\
E_{f s}^{0}-\left[1-s\left(t_{0}+t\right)\right]^{3}-(\kappa-1)\left(E_{f s}^{0}-1\right) & \left(t_{c}<t_{0}+t\right)\end{cases} \\
\text { ここに、 } t_{c}=\frac{1}{s}\left[1-\sqrt[3]{1-(\kappa-1)\left(E_{f s}^{0}-1\right)}\right] &
\end{aligned}
$$

式(3-1)を時間 $t$ に対して積分すると、分散セメント粒子数の経時 変化式は、式(3-6)のように求められる。

$$
\frac{1}{N_{c d}}-\frac{1}{N_{c d 0}}=\frac{8 k T}{3 \eta} \cdot t
$$

ここに、 $N_{c d 0}$ : 流動性の経時変化を考察する始点における分散セメ ント粒子数、 $N_{c d o}=N_{c} \Psi_{0} 、 \Psi_{0}$ : 考察開始点におけるセメント 粒子の分散度

式(3-4)または式(3-5)と式(3-6)を式(2-4)に代入すると、セメント粒 子の平均分散エネルギ障壁 $E_{s s}(t)$ は、式(3-7)のように得られる。

$$
E_{s s}(t)=E_{f}-\left(E_{f}-E_{d}\right) \cdot \frac{\psi_{0}}{1+8 k T \psi_{0} N_{c} t / 3 \eta}
$$

ここに、 $E_{d}$ :分散セメント粒子の平均ポテンシャルエネルギであり、 一定の試料に対して定数
式(3-7)によれば、ポリカルボン酸系の高性能 $\mathrm{AE}$ 減水剤を添加す る場合、セメント粒子の分散ポテンシャルエネルギ障壁は静置時間 の経過に伴って増加する。また、水和物の生成および自由水の減少 とともに、内部摩擦角が大きくなり、高流動コンクリートの真の降 伏値ては增加することになる。したがって、式(2-2)によれば、高流 動コンクリートの見かけ粘度は放固時間とともに大きくなる。

水和生成物による内部摩擦角の変化に関する確認や定量的な把握 は困難である。内部摩擦によって決定される真の降伏值の経時変化 を無視すると、見かけ粘度の経時変化は、式(3-8)で表される。

$$
\left(\eta_{a}\right)_{s s}(t)=\frac{\tau \cdot \exp \left(E_{s s}(t) / k T\right)}{C_{1} \sinh \left[C_{2}\left(\tau-\tau_{y}\right)\right]}
$$

\section{2 Bingham 定数の経時変化}

高速せん断領域における高流動コンクリートの流動曲線は、図 1 に示すように直線で近似できれば、Bingham 定数は、それぞれ式(3-9) と式(3-10)で表させる。

$$
\begin{aligned}
& \eta_{b}=\frac{\tau_{H}-\tau_{L}}{\dot{\gamma}_{H}-\dot{\gamma}_{L}}=\frac{1}{C_{1}} \cdot \frac{\left(\tau_{H}-\tau_{L}\right) \cdot \exp (E / k T)}{\sinh \left[C_{2}\left(\tau_{H}-\tau_{y}\right)\right]-\sinh \left[C_{2}\left(\tau_{L}-\tau_{y}\right)\right]} \\
& \tau_{y b}=\frac{\tau_{L} \dot{\gamma}_{H}-\tau_{H} \dot{\gamma}_{L}}{\dot{\gamma}_{H}-\dot{\gamma}_{L}} \cong \tau_{\mathrm{y}}+\frac{E}{C_{2} k T}+\frac{\dot{\gamma}_{H} \ln \dot{\gamma}_{L}-\dot{\gamma}_{L} \ln \dot{\gamma}_{H}}{C_{2}\left(\dot{\gamma}_{H}-\dot{\gamma}_{L}\right)}+\ln \frac{2}{C_{1}}
\end{aligned}
$$

式(3-9)によって、高流動コンクリートの塑性粘度 $\eta_{b}$ は、セメント 粒子の分散ポテンシャルエネルギ障壁 $E$ の増加に伴って指数曲線的 に増加すること、つまり放置時間 $t$ とともに大きくなることがわか る。また、式(3-10)によれば、降伏値 $\tau_{y b}$ は、摩擦抵抗で決定される 真の降伏値より大きい。その增加分は粘性抵抗と考えられ、セメン ト粒子の分散ポテンシャルエネルギ障壁 $E$ の増加に伴って增加する。 したがって、降伏值も放置時間とともに増加する。

\section{4. せん断応力の持浡に伴う見かけ粘度の变化}

\section{1 載荷状態における見かけ粘度}

擋挥などのせん断力が作用する場合、高流動コンクリートは、そ の中に移動粒子が生じるため、流動する。その流動速度は、セメン 卜粒子群の移動速度に依存し、セメント粒子の平均移動距離と単位 時間に生じた移動セメント粒子の個数との積である7)。たがって、 単位時間に生じた移動セメント粒子の個数、すなわち、移動セメン 卜粒子の発生速度 $(\mathrm{d} \lambda / \mathrm{d} t)$ は、せん断速度 $(\gamma)$ とセメント粒子の平均移 動距離 $\left(\Lambda_{c m}\right)$ の比であり、式(4-1)で表される。

$$
\frac{\mathrm{d} \lambda}{\mathrm{d} t}=\frac{1}{\ddot{E}_{c m}} \cdot \frac{\mathrm{d} \gamma}{\mathrm{d} t}=\frac{1}{\Lambda_{c m}} \cdot \dot{\gamma}
$$

凝集状態のセメント粒子は、せん断外力によって移動すると、分散 状態となり、その個数の減少速度は、凝集粒子数または移動セメント 粒子の発生速度が大きいほど增加すると考えられる。しかし、積分計 算を可能にするために、載荷による疑集セメント粒子の減少速度を、 文献 7)によって凝集セメント数および載荷開始時点における移動セメ ント粒子の発生速度と近似的に比例すると仮定して、式(4-2)で表す。

$$
\left(\frac{\mathrm{d} N_{c f}}{\mathrm{~d} t}\right)_{a s} \approx-\frac{\alpha \cdot \dot{\gamma}_{0}}{\Lambda_{c m}} \cdot N_{c f}
$$

ここに、 $\alpha$ : 比例定数、 $\dot{\gamma}_{0}$ : 載荷開始時点のせん断ひずみ速度 
一方、式(3-1)によって、立体障害反発力が存在する場合には、セ メント粒子の自己凝集による凝集セメント粒子の増加速度は、式 (4-3)で表される。

$$
\left(\frac{\mathrm{d} N_{c f}}{\mathrm{~d} t}\right)_{a s}=\frac{8 k T}{3 \eta} \cdot\left(N_{c}-N_{c f}\right)^{2}
$$

したがって、凝集状態のセメント粒子の経時変化速度は、式(4-4) で表される。

$$
\frac{d N_{c f}}{d t}=-\frac{\alpha \dot{\gamma}_{0}}{\Lambda_{c m}} \cdot N_{c f}+\frac{8 k T}{3 \eta} \cdot\left(N_{c}-N_{c f}\right)^{2}
$$

式(4-4)を時間 $t$ について積分すると、任意時刻における凝集セメ ント粒子の個数が、式(4-5)に示すように求められる。

$$
\begin{aligned}
& N_{c f}= m_{7}-\frac{2 m_{4}}{m_{5} \exp \left(-m_{6} \cdot t\right)+1} \\
& \text { ここに、 } m_{4}=\frac{3 \alpha \eta \dot{\gamma}_{0}}{16 \Lambda_{c m} k T} \cdot \sqrt{\frac{32 k T \Lambda_{c m} N_{c}}{3 \eta \alpha \dot{\gamma}_{0}}+1} \\
& m_{5}=\frac{2 m_{4}}{m_{4}+N_{c d 0}+3 \alpha \eta \dot{\gamma}_{0} / 16 \Lambda_{c m} k T}-1 \\
& \mathrm{~m}_{5}=16 \mathrm{kT} \mathrm{m} / 3 \eta, m_{7}=m_{4}+N_{c}+3 \alpha \eta \dot{\gamma}_{0} / 16 \Lambda_{c m} k T
\end{aligned}
$$

式(3-4)および式(4-5)を式(2-4)に代入すると、セメント粒子の分散 エネルギ障壁が、せん断応力の持続時間とともに変化する関係式と して、式(4-6)のように求められる。

$$
\begin{aligned}
E_{a s}(t) & =E_{d}+ \\
& \frac{1}{N_{c}}\left\{E_{f}^{0}-E_{d}-\left[1-s\left(t_{0}+t\right)\right]^{3}\right\} \cdot\left[m_{7}-\frac{2 m_{4}}{m_{5} \exp \left(-m_{6} t\right)+1}\right]
\end{aligned}
$$

したがって、立体障害反発力が存在する場合では、せん断応力時 の高流動コンクリートのせん断ひずみ速度および見かけ粘度は、載 荷の持続時間に依存し、式(4-6)を式(2-1)と式(2-2)に代入して、式 (4-7)のように算出される。

$$
\begin{aligned}
& \dot{\gamma}_{t}=C_{1} \exp \left(-E_{a s}(t) / k T\right) \cdot \sinh \left[C_{2}\left(\tau-\tau_{y}\right)\right] \\
& \left(\eta_{a}\right)_{a s}(t)=\frac{\tau \cdot \exp \left(E_{a s}(t) / k T\right)}{C_{1} \sinh \left[C_{2}\left(\tau-\tau_{y}\right)\right]}
\end{aligned}
$$

\section{2 見かけ粘度が変化する条件}

式(4-6)を載荷持続時間 $t$ について微分すると、式(4-8)が得られる。

$$
\begin{aligned}
\frac{\mathrm{d} E_{a s}(t)}{\mathrm{d} t}= & \frac{3 s\left[1-s\left(t_{0}+t\right)\right]^{2}}{N_{c}} \cdot\left(m_{7}-\frac{2 m_{4}}{m_{5} \exp \left(-m_{6} t\right)+1}\right) \\
& -\frac{E_{f}^{0}-E_{d}-\left[1-s\left(t_{0}+t\right)\right]^{3}}{N_{c}} \cdot \frac{2 m_{4} m_{5} m_{6} \exp \left(-m_{6} t\right)}{\left[m_{5} \exp \left(-m_{6} t\right)+1\right]^{2}}
\end{aligned}
$$

式(4-8)の右辺に正值、負值および零をとれば、擋汼などのせん断 外力が作用する場合の、高流動コンクリート試料の見かけ粘度が増 加または減少する条件として、初期せん断ひずみ速度の範囲、およ び見かけ粘度が平衡状態に達する載荷持続時間を数値計算によって 求めることが可能であるが、式で表現することは困難である。

高性能 $\mathrm{AE}$ 減水剈が過剩添加される場合、または $\mathrm{C}_{3} \mathrm{~A}$ 反応の誘導期 には、セメント粒子の分散エネルギ障壁に及ぼす水和生成物の影響が 小さく、これを無視すれば、式(4-6)の微分式は、次式のようになる。

$$
\frac{\mathrm{d} E_{a s}(t)}{\mathrm{d} t} \cong-\frac{E_{f}^{0}-E_{d}}{N_{c}} \cdot \frac{2 m_{4} m_{5} m_{6} \exp \left(-m_{6} t\right)}{\left[m_{5} \exp \left(-m_{6} t\right)+1\right]^{2}}
$$

式(4-9)の右辺が正値になる条件、つまり見かけ粘度が載荷持続時 間とともに増加する条件は、式(4-10)で表される。

$$
\dot{\gamma}_{0}<\frac{8 k T \Lambda_{c m}}{3 \alpha \eta} \cdot \frac{N_{c d 0}^{2}}{N_{c}-N_{c d 0}}
$$

この場合には、セメント粒子の凝集速度は分散速度よりも大きく、 せん断応力が一定であっても、せん断ひずみ速度は載荷持続時間之 ともに平衡状態まで減少し、見かけ粘度が増加する。また、この現 象が生じる初期せん断速度の上限は、温度または載荷開始時点にお けるセメント粒子の分散程度が大きいほど大きい。

一方、見かけ粘度が載荷持続時間とともに下降する条件は、式(4-9) の右辺を負値にして、式(4-11)のように得られる。

$$
\dot{\gamma}_{0}>\frac{8 k T \Lambda_{c m}}{3 \alpha \eta} \cdot \frac{N_{c d 0}^{2}}{N_{c}-N_{c d 0}}
$$

この場合は、セメント粒子の分散速度が大きく、せん断応力が一 定でも、せん断ひずみ速度はその持続時間とともに平衡状態まで增 加し、見かけ粘度の減少が生じる。また、この現象の初期せん断速 度の下限は、温度または載荷開始時点におけるセメント粒子の分散 程度が大きいほど大きい。

\section{3 見かけ粘度が一定になる条件}

見かけ粘度が初期值のまま変わらない条件は、式(4-12)となる。

$$
\dot{\gamma}_{0}=\frac{8 k T \Lambda_{c m}}{3 \alpha \eta} \cdot \frac{N_{c d 0}^{2}}{N_{c}-N_{c d 0}}
$$

上式が成立する場合には、載荷によるセメント粒子の分散速度は その物理凝集速度と等しく、せん断ひずみ速度および見かけ粘度は 初期值のまま持続する。

また、水和生成物によるセメント粒子の凝集傾向の増加を無視す ると、式(4-6)によって、擋拌などの外力がある時間まで持続して作 用すれば、分散エネルギ障壁はほぼ一定値になり、平衡状態に達す る。平衡状態における分散エネルギ障壁 $E_{\text {as-e }}$ および見かけ粘度 $\left(\eta_{a}\right)_{a s-e}$ は、それぞれ式(4-13)のように表される。

$$
E_{a s-e}=E_{d}+\left(E_{f}^{0}-E_{d}\right) \cdot \frac{m_{7}-2 m_{4}}{N_{c}},\left(\eta_{a}\right)_{a s-e}=\frac{\tau \cdot \exp \left(E_{a s-e} / k T\right)}{C_{1} \sinh \left[C_{2}\left(\tau-\tau_{y}\right)\right.}
$$

$\left(m_{7}-2 m_{4}\right) / N_{c}$ の值は 1 より小さく、初期のせん断ひずみ速度 $\left(\gamma_{0}\right)$ の増

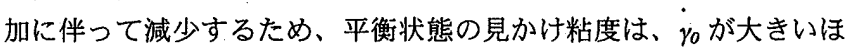
ぞ小さい。

見かけ粘度の計測誤差を $e(<1)$ と記すれば、計測された平衡状態の 分散障壁 $\left(E_{a s-c}\right)_{m}$ は、式(4-14)によって表される。

$$
\left(E_{a s-e}\right)_{m}=(1 \pm e) \cdot E_{a s-e}
$$

ここに、見かけ粘度が下降する場合には $e$ は正值であるが、增加 する場合には負値を取る。

式(4-14)の方程式を解くと、見かけ粘度が平衡状態に達するまでの 載荷持続時間の計測值 $t_{e}$ は、式(4-13)のように求められる。

$$
t_{e}=\frac{1}{m_{6}} \ln \left\{m_{5} \cdot\left[\frac{2 m_{4}\left(E_{f}^{0}-E_{d}\right)}{N_{c} k T \ln (1 \pm e)}\right]\right\}
$$




\section{5. チキントロピー特性}

非ニュートン流体の流動曲線を、載荷と除荷を連続して測定すれ ぱ、下降曲線は、内部構造の破濖・復元によって、図 5 に示すよう

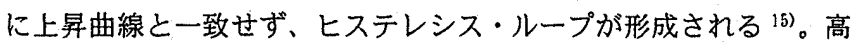
濃度サスペンションである高流動コンクリートは、載荷されると、 セメント粒子の凝集構造の破塤・復元が発生するため、その流動挙 動がせん断履歴の影響を受け、ずり速度チキソトロピーを示すと考 えられる。以下には、ヒステレシス・ループの形状および面積につ いて考察することによって、高流動コンクリートのチキソトロピー 特性を検討する。

式(4-5) および式 (4-6)によって、図 5 に示すヒステレシス・ルー プ上の各点におけるセメント粒子の分散ポテンシャルエネルギ障壁 は、式(5-1)のように求められる。

$$
\begin{aligned}
& E_{1}=E_{d}+\frac{N_{c f 1}}{N_{c}} \cdot E_{r} \\
& E_{2}=E_{d}+\frac{N_{c f 2}}{N_{c}}\left\{E_{r}-\left[1-s\left(t_{0}+\Delta t_{1}\right)\right]^{3}\right\} \\
& \vdots \\
& E_{i}=E_{d}+\frac{N_{c f i}}{N_{c}}\left\{E_{r}-\left[1-s\left(t_{0}+\Delta t_{1}+\Delta t_{2}+\cdots \Delta t_{i-1}\right)\right]^{3}\right\}
\end{aligned}
$$

ここに、 $E_{r}=E_{f}^{\theta}-E_{d} 、 N_{c f}:$ 第 $i$ 回の載荷開始時点における凝集セメ

ント粒子の個数、 $\Delta t_{i}:$ 第 $i$ 回の載荷持続時間

$$
\begin{aligned}
& N_{c f 2}=m_{7-1}-\frac{2 m_{4}}{m_{5-1} \exp \left(-m_{6-1} \cdot \Delta t_{1}\right)+1} \\
& N_{c f i}=m_{7-(i-1)}-\frac{2 m_{4-(i-1)}}{m_{5-(i-1)} \exp \left(-m_{6-(i-1)} \cdot \Delta t_{(i-1)}\right)+1} \\
& m_{4-(i-1)}=\frac{3 \alpha \eta \dot{\gamma}_{0(i-1)}}{16 \Lambda_{c m} k T} \cdot \sqrt{\frac{32 k T \Lambda_{c m} N_{c}}{3 \alpha \eta \dot{\gamma}_{0(i-1)}}+1} \\
& m_{5-(i-1)}=\frac{2 m_{4-(i-1)}}{m_{4-(i-1)}+N_{c}-N_{c f(i-1)}+3 \alpha \eta \dot{\gamma}_{0(i-1)} / 16 \Lambda_{c m} k T}-1 \\
& m_{6-(i-1)}=\frac{16 k T m_{4-(i-1)}}{3 \eta}, m_{7-(i-1)}=N_{c}+\frac{3 \alpha \eta \dot{\gamma}_{0(i-1)}}{16 \Lambda_{c m} k T}+m_{4-(i-1)}
\end{aligned}
$$

したがって、ヒステレシス・ループ上の各点のせん断ひずみ速度 は、式(2-1)および式(5-1)によって、次式のように算出される。

$$
\begin{gathered}
\dot{\gamma}_{1}=C_{1} \exp \left(-E_{1} / k T\right) \sinh \left[C_{2}\left(\tau_{1}-\tau_{y}\right)\right] \\
\dot{\gamma}_{2}=C_{1} \exp \left(-E_{2} / k T\right) \sinh \left[C_{2}\left(\tau_{2}-\tau_{y}\right)\right] \\
\vdots \\
\dot{\gamma}_{i}=C_{1} \exp \left(-E_{i} / k T\right) \sinh \left[C_{2}\left(\tau_{i}-\tau_{y}\right)\right]
\end{gathered}
$$

ここに、 $\tau_{i}, \dot{y}_{i}:$ それぞれ各点のせん断応力および載荷直後の瞬時 せん断ひずみ速度

ヒステレシス・ループの形状および面積に及ぼす影響要因は、式 (5-2)からは直観的にわからないため、6.3 節に示す数値計算によっ て明らかにする。

\section{6. 解析例および考察}

ここまでの理論的な検討結果の妥当性に関しては、実験による検 証が必要であるが、実験過程における試料の分離が避けられないこ とや測定装置の問題で、フレッシュコンクリートのレオロジー挙動 の精確な計測は難しいため、今後の課題とする。以下では、以上の 理論式に基づいて、数值計算を行い、高流動コンクリートのフレッ シュ性状の経時変化特性とチキソトロピー特性およびそれらの影響 要因について検討する。

\section{1 流動曲線}

山本らは、J 型フロー試験器および回転粘度計を用いて、高流動 コンクリートの低せん断速度域と高せん断速度域における流動曲線 を測定した ${ }^{16)}$ 。3 シリーズの試料の調合および実験結果をそれぞれ 表 1 および図 6 に転記する。

式(2-1)に示す高流動コンクリートの流動曲線式中の各パラメータ を表 2 に示すように設定して、数値計算を行い、異なるせん断応力 下のせん断ひずみ速度を求めた。図 6 に計算結果を実験結果と併示 する。同図に示すように、計算值は実測値とよく一致しており、式 (2-1)の妥当性が確認できる。

\section{2 見かけ粘度およびBingham 定数の静置による变化}

流動性状の経時変化およびチキソトロピー特性に対する数值解析 の対象試料としては試料 $\mathrm{K}$ を用いた。解析用の一部のパラメー夕は 流動曲線の解析用のパラメータと同じであり、それらの值を表 2 中 のシリーズ K に示すが、追加パラメータの設定値は、流動性状の経 時変化に関する解析の場合には表 3 の $\mathrm{K}_{1}$ シリーズに、チキソトロピ

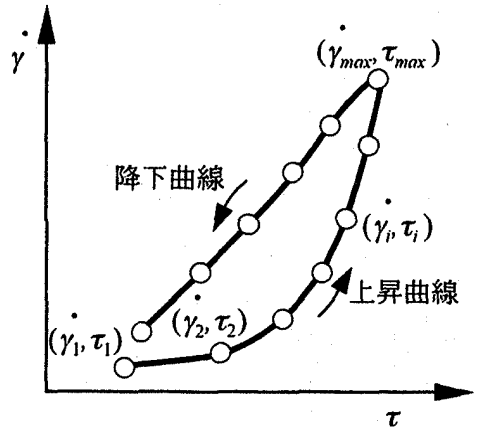

図 5 高流動コンクリートのヒス テレシス・ループ

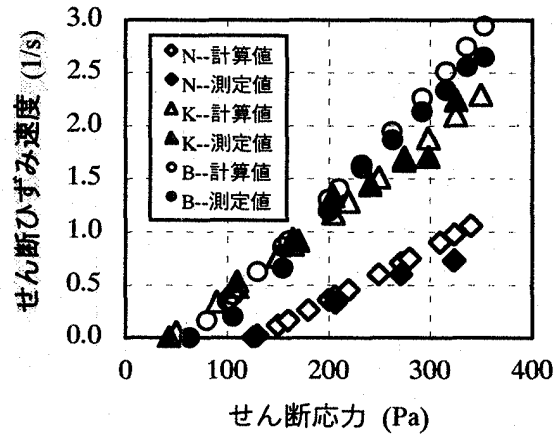

(a) J型フロー試験

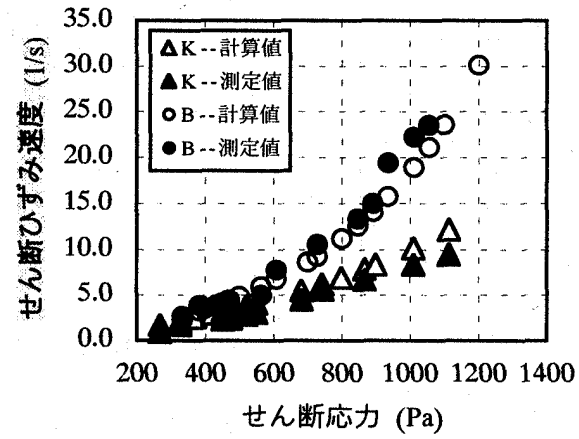

(b) 二重円筒回転粘度計

図6 流動曲線の測定結果 ${ }^{16)}$ と計算結果の比較 
一特性に関する解析の場合には $\mathrm{K}_{2}$ シリーズに示す。表 2 と表 3 の各 パラメータの値を、文献 7 8, 16 18)および試算によって設定した。

図 7 は、5 分間で練り上げた高流動コンクリート試料 $\mathrm{K}$ の見かけ粘 度の、静置時間に伴う変化を示したものである。試料 $\mathrm{K}$ の見かけ粘度 が静置時間とともに増加するが、経時変化グラフは 3 つの部分に分け られ、それぞれセメント粒子の水和反応の接水初期、誘尊期および加 速期に対応している。練り上がり直後には、セメント粒子の水和反応 速度が速いため、見かけ粘度の増加が速いが、誘導期に入ると遅くな る。水和反応が激しい加速期では見かけ粘度は時間とともに急増する。 これらの区間をそれぞれ水和初期、緩慢期および加速期と呼ぶ。

次に、シリーズ $\mathrm{K}_{1}$ を基本シリーズとし、そのパラメータ $E_{f}^{0}, E_{f f}^{0}, \Psi_{0}, T$, $s, t_{0}$ の值を変化させ、高性能 $\mathrm{AE}$ 減水剤の添加量、セメント粒子の初期 分散度、温度、セメント粒子の反応率およびセメント接水から考察開 始までの時間(始点時間と呼ぶことにする)が高流動コンクリートの見 かけ粘度の経時変化に与える影響をそれぞれ考察した。図 7 に示すよ うに、経時変化の始点時間 $t_{0}$ は結果に大きく影響を与え、 $t_{0}$ が $15 \mathrm{~min}$. である場合においては水和反応の加速期に入ったため、経時変化が激 しい。考察始点におけるセメント粒子の初期分散度を大きくするほど 見かけ粘度は小さく、初期の経時変化も小さい。これらは、練混ぜ時 間および載荷の履歷が、高流動コンクリートの見かけ粘度の経時変化 に影響を与えることを示唆している。また、高性能 $\mathrm{AE}$ 減水剤の添加 量が大きいほど、水和反応初期における見かけ粘度の経時変化速度は 小さく、過剩添加の場合には流動性は一定時間保持できる。なお、温 度またはセメントの反応率の増加に伴って経時変化速度は大きくなる。

図 8 は、試料 KK擋汼などのせん断外力を加えた後の見かけ粘度 の経時変化図である。セメントの水和反応の初期または誘導期に摚 拌すると、経時変化の緩慢期は長くなり、加速期は延期される。試 料 $\mathrm{K}$ の Bingham 定数の静置による経時変化を図 9 に示す。同図によ れば、Bingham 定数は、静置時間とともに増加し、その経時変化速

\begin{tabular}{|c|c|c|c|c|c|c|c|c|c|c|}
\hline \multirow[b]{2}{*}{$\begin{array}{l}\text { 試 } \\
\text { 料 }\end{array}$} & \multirow[b]{2}{*}{$\begin{array}{l}\text { セメント } \\
\text { の種類 }\end{array}$} & \multirow[b]{2}{*}{$\begin{array}{l}\mathrm{W} / \mathrm{C} \\
(\%)\end{array}$} & \multirow[b]{2}{*}{$\begin{array}{l}\text { s/a } \\
(\%)\end{array}$} & \multirow{2}{*}{$\begin{array}{ll}\text { 高 } & \text { 性 } \\
\mathrm{AE} & \text { 㴰 } \\
\text { 減 } & \text { 水 } \\
(\mathrm{C} \times \% \%)\end{array}$} & \multicolumn{4}{|c|}{ 単位量 $\left(\mathrm{kg} / \mathrm{m}^{3}\right)$} & \multirow[b]{2}{*}{$\begin{array}{l}\text { Sl. } \\
(\mathrm{cm})\end{array}$} & \multirow[b]{2}{*}{$\begin{array}{l}S f . \\
(\mathrm{cm})\end{array}$} \\
\hline & & & & & 水 & $\begin{array}{l}\text { セx } \\
\text { ント }\end{array}$ & 砂 & 砕石 & & \\
\hline $\mathrm{N}$ & 普通 & 25 & 50 & 5.33 & 144 & 576 & 839 & 839 & 23.7 & 51.5 \\
\hline K & 高炬 B 種 & 23 & 50 & 4.00 & 139 & 596 & 817 & 817 & 28.0 & 69.5 \\
\hline B & B ライト & 25 & 50 & 2.82 & 149 & 596 & 817 & 817 & 23.0 & 59.5 \\
\hline
\end{tabular}

表 2 式(2-1)における各パラメータの計算值および設定值

\begin{tabular}{|c|c|c|c|c|c|c|c|c|c|c|}
\hline $\begin{array}{l}\text { 試 } \\
\text { 料 }\end{array}$ & $\begin{array}{c}\tau_{y} \\
(\mathrm{~Pa})\end{array}$ & $S_{d}$ & $\begin{array}{c}T \\
(\mathrm{k})\end{array}$ & $\begin{array}{c}N_{c} \\
\left(10^{11}\right) \\
\end{array}$ & $\begin{array}{c}\Lambda_{c m} \\
\left(10^{-12} \mathrm{~m}\right) \\
\end{array}$ & $\begin{array}{r}E_{f} \\
(\mathrm{kT})\end{array}$ & $\begin{array}{c}E_{d} \\
(\mathrm{kT})\end{array}$ & $\Psi_{0}$ & $\begin{array}{c}C_{l} \\
\left(10^{13}\right)\end{array}$ & $\begin{array}{c}C_{2} \\
\left(10^{-3}\right) \\
\end{array}$ \\
\hline $\mathrm{N}$ & 126 & $0.322 \mid$ & 293 & 1.6775 & 8.0 & 41 & 5 & 0.300 & 1.6 & 1.90 \\
\hline K & 43.1 & 0.322 & 293 & 1.8891 & 7.5 & 41 & 5 & 0.315 & 1.7 & 1.62 \\
\hline B & 62.8 & 0.329 & 293 & 1.6839 & 10.0 & 41 & 5 & 0.305 & 2.1 & 2.42 \\
\hline
\end{tabular}

表 3 試料 K に対する解析用の追加パラメータの設定值

\begin{tabular}{c|c|c|c|c|c|c|c|c|c}
\hline Series & $\begin{array}{c}E_{f}^{0} \\
(\mathrm{kT})\end{array}$ & $\begin{array}{c}E_{f s}{ }^{0} \\
(\mathrm{kT})\end{array}$ & $\Psi_{0}$ & $\begin{array}{c}s \\
\left(10^{-2}\right)\end{array}$ & $B$ & $\begin{array}{c}\alpha \\
\left(10^{-16}\right)\end{array}$ & $\begin{array}{c}\eta \\
(\mathrm{Pa} \cdot \mathrm{s})\end{array}$ & $\begin{array}{c}t_{0} \\
(\mathrm{~min} .)\end{array}$ & $\begin{array}{c}\Delta t \\
(\mathrm{~min} .)\end{array}$ \\
\hline \hline $\mathrm{K}_{1}$ & 41 & 38 & 0.315 & 3.5 & 2000 & 5.0 & $1.0 \times 10^{-3}$ & 5 & $/$ \\
\hline $\mathrm{K}_{2}$ & 41 & $/$ & 0.340 & 2.5 & $/$ & 5.0 & $1.0 \times 10^{-3}$ & 18 & 2.5 \\
\hline
\end{tabular}

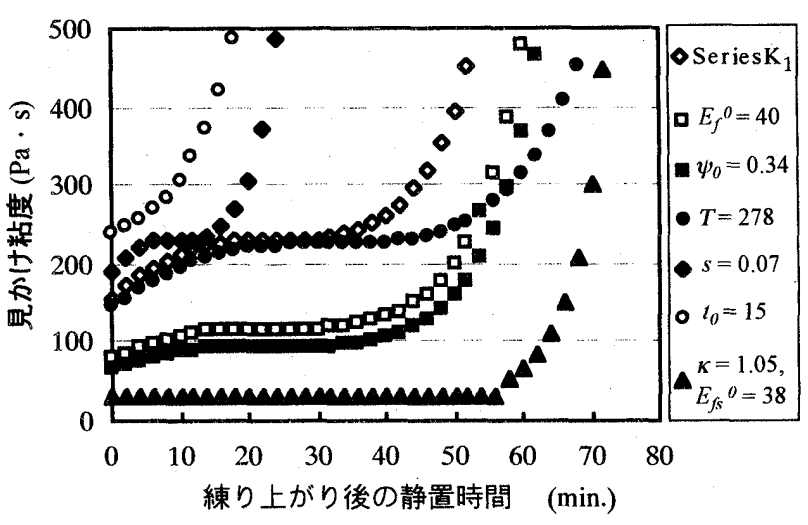

図7 見かけ粘度に及ぼす練り上がり直後の静置時間の影響

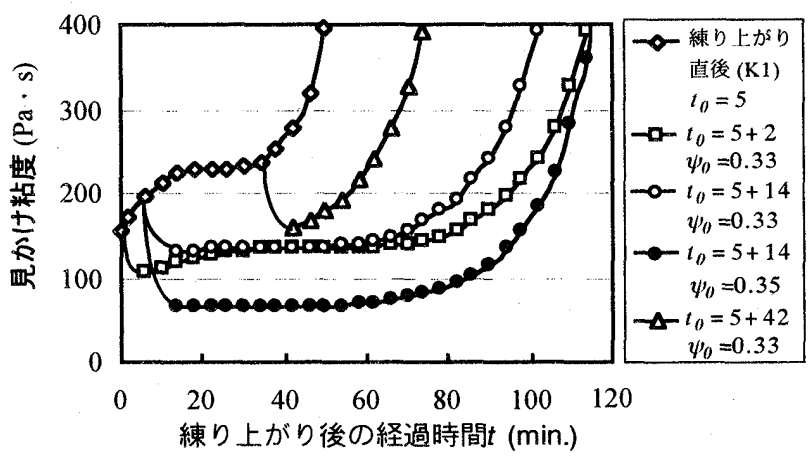

図8 異なる時点に再擋挥された後の静置による見かけ粘 度の経時変化

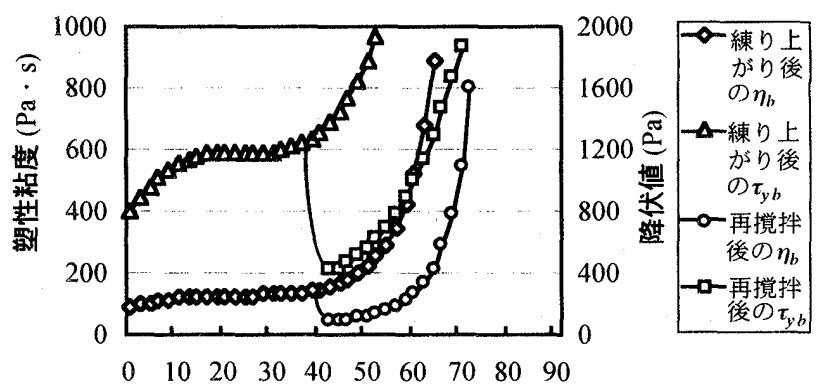

練り上がり後の時間経過 (min.)

図9 練り上がり後および再擋汼後のBingham定数の 静置による経時変化 (Series $\mathbf{K}_{\mathbf{1}}$ )

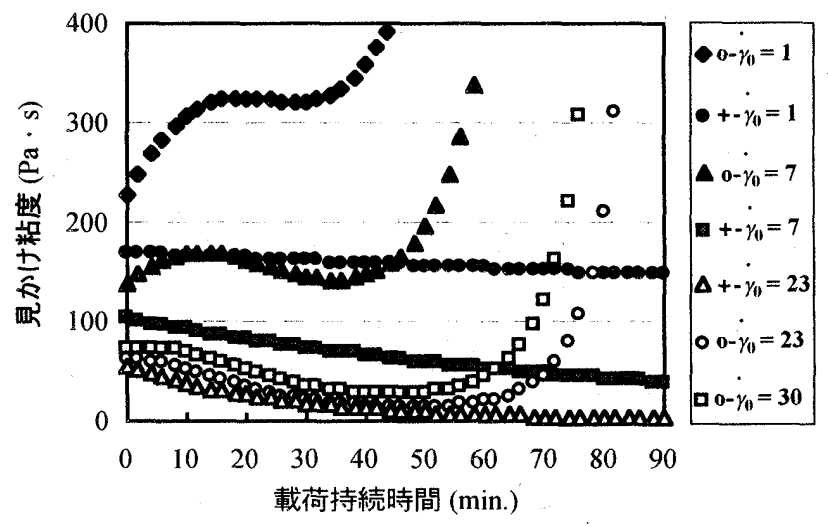

図10 持続載荷による見かけ粘度の変化 (水和反応の影 響を考慮する場合：○、考慮しない場合：+) 
度はセメントの水和反応期によって異なる。また、摚汼後の増加速 度も擋汼される時点に依存することがわかる。

\section{3 載荷による見かけ粘度の経時変化}

図 10 および図 11 は、異なる外力を加えることによって載荷瞬時に おける初期のせん断ひずみ速度 $\gamma_{0}$ を変化させた場合の、試料 Kの見か け粘度と載荷持続時間の関係を示したものである。水和反応を考慮す ると、持続載荷によって、経時変化の緩慢期は長くなり、せん断応力 が一定でも、見かけ粘度は緩慢期では減少するが、水和反応による増 加が卓越する初期および加速期では、時間経過とともに增加する。し かし、せん断ひずみ速度がある程度以上大きくなると、水和反応の初 期においても、見かけ粘度の減少が生じる。

一方、水和反応の影響を考慮しない場合には、ある程度以上のせん 断応力が持続されれば、図 10 に示すように、見かけ粘度は載荷持続 時間とともに減少し、その低下速度は開始時点のせん断速度が大きい ほど大きい。また、図 11 に示すように、見かけ粘度が開始値のまま 変化しないせん断速度が存在し、增加傾向の場合には初期のせん断速 度 $\gamma_{0}$ が小さいほど、または減少傾向の場合には $\gamma_{0}$ が大きいほど、見か け粘度が平衡値になるまでの載荷持続時間は大きい。

図 12 は、初期のせん断ひずみ速度 $\gamma_{0}$ が 71/s の場合において、試料 $\mathrm{K} の$ 見かけ粘度の経時変化、およびシリーズ $\mathrm{K}_{1}$ を基本シリーズとし て、そのパラメータ $E_{f}^{0}, E_{f s}^{0}, \Psi_{0}, T, s, t_{0}$ の值を変化させ、高性能 $\mathrm{AE}$ 減水戍の添加量、セメント粒子の初期分散度、環境温度、セメント の反応率および始点時間などの影響を示したものである。同図によ って、高性能 $\mathrm{AE}$ 減水剤の添加量やセメント粒子の初期分散度の增 加または温度や反応率の低下とともに、見かけ粘度の隇少が発生す る緩慢期は長くなり、高性能 $\mathrm{AE}$ 減水刘を過剩添加したシリーズ $\left(\kappa=1.05, E_{f s}^{0}=38\right)$ は、ある時間まで見かけ粘度が滅少する。また、始 点時間 $t_{0}$ が経時変化に与える影響も見られる。

\section{4 ヒステレシス・ループのせん断履歴の影響}

図 13 は、せん断応力の載荷之除荷の段階数および各段階の応力の 大きさが同じの場合において、異なる応力の持続時間に対して解析し た試料 $\mathrm{K}$ のヒステレシス・ループである。いずれのシリーズも考察開 始時点はセメント接水から 18 分後であり、セメントの水和反応の誘道 期に入る。同図によって、応力の持続時間がある程度以下の範囲では、 下降曲線は上昇曲線の上方にある直線で表され、ループが囲む面積は、 応力の持続時間とともに増加する。応力の持続時間がある程度以上に なると、下降曲線の後半は上舁曲線の下方にくる。応力の持続時間を さらに増加すると、応力を増加しても、せん断ひずみ速度は低下し、 下降曲線の全体が上昇曲線の下方となる。これは、応力の持続時間を ある程度以上に長くすると、セメントの水和反応加速期に入って、水 和物の急增によって、せん断ひずみ速度が大きく低下するためである。 始点時間 $t_{0}$ が試料 $\mathrm{K}$ のヒステレシス・ループに与える影響を図 14 に示す。施がある程度まで大きくなると、ループが囲む面積は小さく なる。これは、 $t_{0}$ が大きいほど、水和反応速度が大きく、下降曲線に おける水和生成物による減少速度が大きいためである。また、 $t_{0}$ がさ らに大きくなると、セメントの水和反応加速期に入いるため、下降曲 線は上昇曲線の下方に位置する。

図 15 は、応力の段階数および各段階のせん断応力の大きさが試料

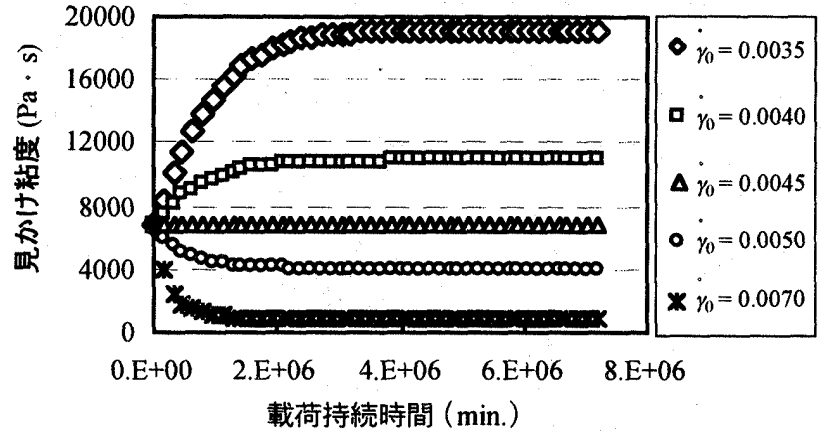

図11 セメントの水和生成物の影響を考虑しない場合にお ける見かけ粘度と載荷持続時間の関係 (Series $\mathbf{K}_{1}$ )

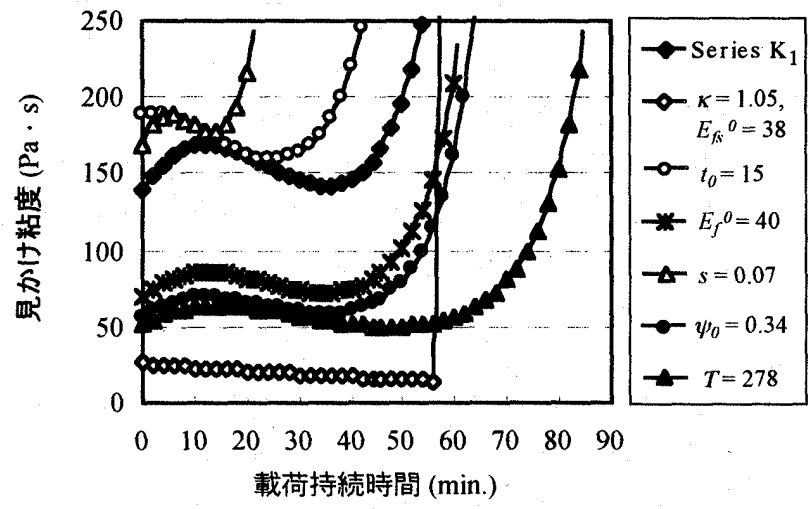

図12 セメントの水和生成物の影響を考虑した場合の 見かけ粘度の経時変化に及ぼす各種要因の影響

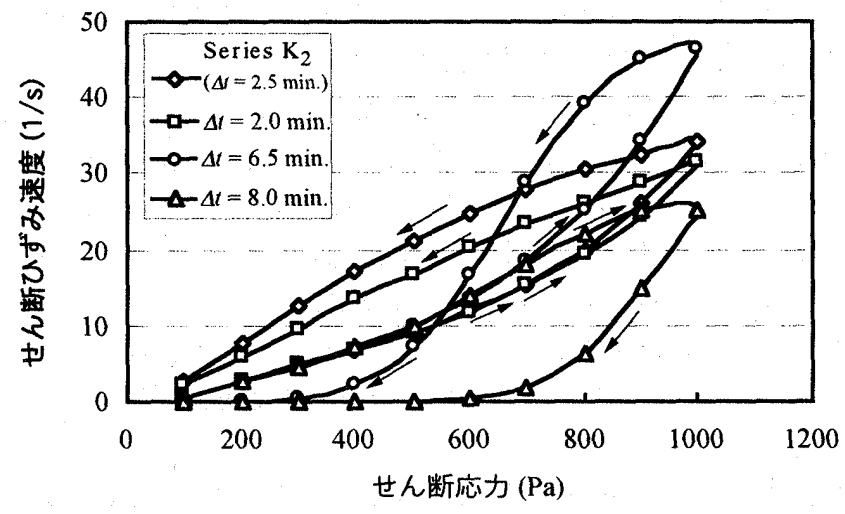

図13 ヒステレシス・ループに及ぼす載荷持続時間の影響

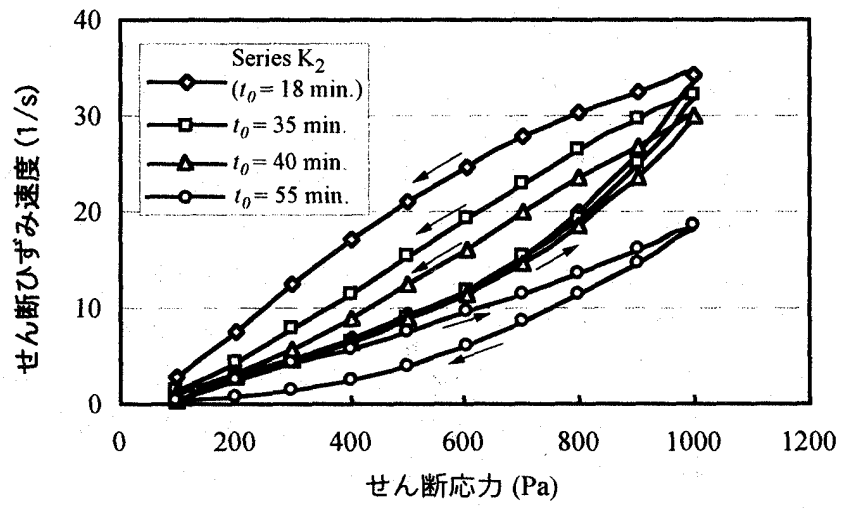

図14 ヒステレシス・ループに及ぼす始点時間の影響 


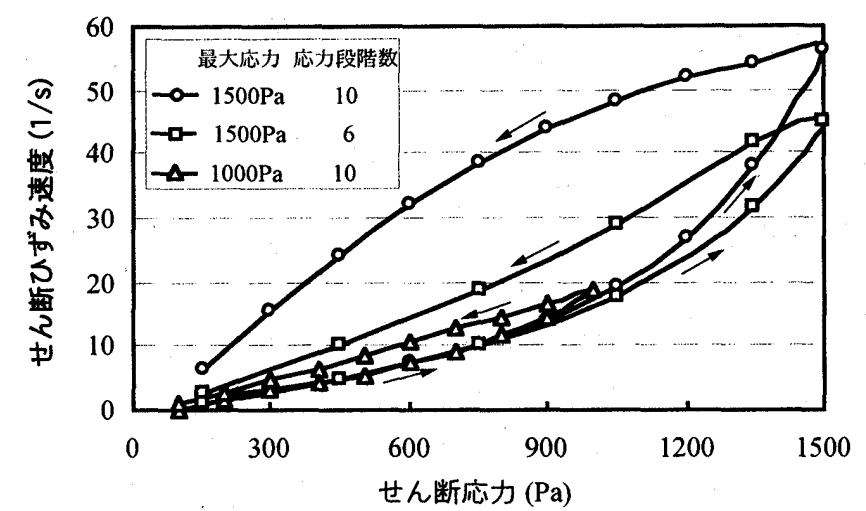

図15持続時間が一定時のヒステレシス・ループに及ぼす せん断応力の大きさと応力段階数の影響 (Series $\mathbf{K}_{\mathbf{2}}$ )

Kのヒステレシス・ループに及ぼす影響を示したものである。同図 よれば、最大せん断応力および応力の持続時間が同じ場合は、応力 の段階数は多いほど、または応力の段階数および応力の持続時間が 同じ場合は、各点の応力が大きいほど、ヒステレシス・ループに囲 まれる面積は大きくなる傾向が見られる。

\section{7. まとめ}

本研究では、高流動コンクリートの見かけ粘度の経時変化とチキ ソトロピー性について理論的な考察および数值解析を行った。得ら れた結果は、以下のようにまとめられる。

1) 見かけ粘度の経時変化は、セメント粒子の Brown 運動による衝 揧凝集および水和反応生成物に起因する。その速度は、セメント の水和反応速度に強く依存し、接水初期および水和反応加速期で は、水和反応速度の影響が粒子の物理凝集よりも支配的である。 2）見かけ粘度は静置時間とともに増加する。その増加速度は、高性 能 $\mathrm{AE}$ 減水剂の添加量が多いほど初期では小さく、過剩添加の場合 の見かけ粘度はある時間までは一定值を維持する。また、温度また はセメントの反応率の増加に伴って、増加速度は大きくなり、考察 始点の時刻およびセメント粒子の初期分散度の影響を受ける。

3) Bingham 定数は静置によって增加し、経時変化の速度に対する影 響要因は、見かけ粘度の静置による経時変化の影響要因と同じで ある。

4) 水和反応の誘導期や、高性能 AE 隇水剤の過㮃添加の場合など、 セメントの水和反応の影響が無視できる場合、ある程度以上のせ ん断応力を持続すると、見かけ粘度は載荷持続時間とともに減少 し、ある時間後には平衡状態に達する。せん断応力が大きいほど、 見かけ粘度の減少速度は大きく、平衡状態に達するまでの時間も 大きい。また、ある程度以下のせん断応力を持続すると、見かけ 粘度は逆に增加する。この場合の増加速度および平衡状態に達す るまでの時間は、せん断応力が小さいほど大きい。

5) セメントの水和反忘の影響を考慮した場合、荷重の持続による見 かけ粘度の增加または減少は、維持されているせん断応力および セメントの水和反応率に依存する。せん断応力の増加に伴って、 滅少する時間が長くなる。減少速度は高性能 $\mathrm{AE}$ 減水剤の添加量、 セメント粒子の反応率と初期分散度、温度および考察始点の時刻 の影響を受ける。

6) 高流動コンクリートのヒステレシス・ループの下降曲線と上昇曲
線の位置関係は、加えたせん断応力とセメントの水和反応速度に 依存する。下降曲線は、セメントの反応速度が低い誘導期におい てはほほ直線で表され、上昇曲線の上方に位置するが、セメント の水和反応が加速期に入れぱ、逆に上昇曲線の下方にくる。前者 の場合のループで囲まれる面積は、持続応力またはその持続時間 が大きいほど大きい。

\section{考支献}

1) 上木学会 : 高流動コンクリートに関する技術の現状と課題, pp.1-39, 1996.11.

2）超流動コンクリート研究委員会報告書(I), 日本コンクリートエ学協会, pp.1-56, 1993.5

3) Hu, C. and Lefebvre, F. D. : The rheology of fresh high-performance concrete, Cement and Concrete Research, Vol.26, №.2, pp.283-294, 1996.

4) Pellerin, B. : Assessment of thixotropic behavior of self-compacting concrete, Proceedings of the Second International Symposium on Self-compacting Concrete (Tokyo), pp.10-15, 2001.10.

5) Billerg, P. : Thixotropy of self-compacting concrete, Proceedings of the Second International Symposium on Self-compacting Concrete (Tokyo), pp.10-15, 2001.10.

6）桝田佳寛ほか : 淮高流動コンクリートの基硭研究(その 2), 日本建策学会大 会学術部演梗概集, pp.977-978, 1998.9.

7) Zhuguo $\mathrm{Li}$ : Investigation on the shear flow of self-compacting concrete, Proceedings of the Second International Symposium on Self-compacting Concrete (Tokyo), pp.10-15, 2001.10.

8) 坂井悦郎, 大門正機 : 粒子間ポテンシャルの計算による高性能 AE 減水骫 の作用機構，セメント・コンクリート, No.595, pp.13-22, 1996.9.

9) Everett, D. H.著, 関集三ほか訳 : コロイド科学の基䃈, 化学同人, pp.47-149, 2000.3.

10) 服部健一 : スランプロスのメカニズムおよびその対策, 材料, Vol.29, No.318, pp.34-40, 1980.3 .

11）棡田英三郎 : スランプロス・流動化コンクリートの応用, セメント・コン クリート化学とその応用, セメント協会, pp.141-147, 1994.1.

12）营俣匠，日比野破，大内雅博，岡村甫：ポリカルボン酸系高性能 $\mathrm{AE}$ 減水 剤の粒子分散作用に関する考察，コンクリート工学年次論文報告集，Vol.21， No.2, pp.91-96, 1999.

13) 長流重義, 坂井悦郎, 尾崎大輔: 高性能 $\mathrm{AE}$ 減水郕を添加したコンクリー トのスランプロス, セメント技術年報, Vol.35, pp.210-213, 1981.

14) 日本コンクリートエ学協会: 反応モデル解析研究委員会報告書(I), pp.6-24, 1996.5 .

15) 中川鶴太郎, 神戸博太郎 : レオロジー, みすず㫪屏, pp.456-466, 1965.

16) 山本康弘, 本關礼人, 槅高義典: 高流動コンクリートの流動特性の試駼方 法(J 型フロー試臥)に関する研究, 日本建築学会構造系論文集, No.489, pp.9-16, 1996.11.

17) 吉野公ほか: 高流動コンクリートの望性粘度予测に関する研究, フレッシ ユコンクリートの流動性と施工性に関するシンポジウム, pp.13-18, 1996.4.

18）水口裕之 : フレッシュコンクリートの流動特性に関する基做研究, pp.66-68, 1984.2. 